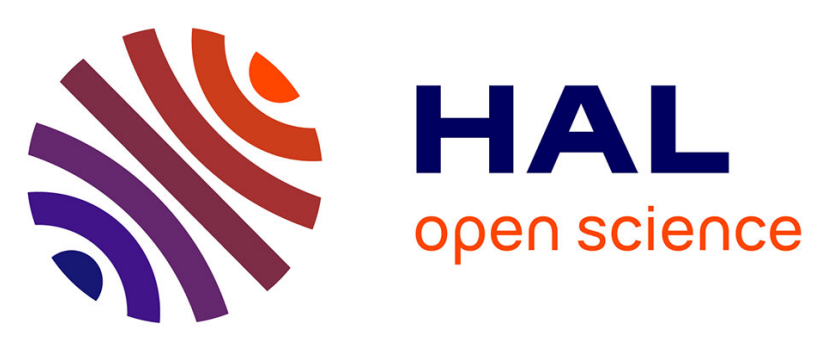

\title{
Adjusting food practices to climate prescriptions: vegetable gardening as a way to reduce food-related greenhouse gas emissions
}

Laurence Granchamp

\section{- To cite this version: \\ Laurence Granchamp. Adjusting food practices to climate prescriptions: vegetable gardening as a way to reduce food-related greenhouse gas emissions. Review of Agricultural, Food and Environmental Studies, 2019, 100 (1-4), pp.1-25. 10.1007/s41130-019-00087-7 . hal-02572962}

\author{
HAL Id: hal-02572962 \\ https://hal.science/hal-02572962
}

Submitted on 13 Jul 2020

HAL is a multi-disciplinary open access archive for the deposit and dissemination of scientific research documents, whether they are published or not. The documents may come from teaching and research institutions in France or abroad, or from public or private research centers.
L'archive ouverte pluridisciplinaire HAL, est destinée au dépôt et à la diffusion de documents scientifiques de niveau recherche, publiés ou non, émanant des établissements d'enseignement et de recherche français ou étrangers, des laboratoires publics ou privés. 


\title{
Adjusting food practices to climate prescriptions: vegetable gardening as a way to reduce food-related greenhouse gas emissions
}

\author{
Laurence Granchamp ${ }^{1}$
}

Received: 11 February 2016 / Accepted: 20 May 2019 / Published online: 9 July 2019

(C) INRA and Springer-Verlag France SAS, part of Springer Nature 2019

\begin{abstract}
During a survey of an experiment that involved using "carbon calculators", we investigated what people think and what they do when they consider the link between their food and the climate. To what extent do individuals adhere to or reject the "prescriptions" implicitly contained in carbon calculators and passed on by environmental social movements or the authorities. These prescriptions are considered as recommendations or advice drawn up by experts aiming to guide behaviours; they involve reducing reality in a measuring device against which behaviours are gauged (in this case, the quantity of greenhouse gases). Three main levers are envisaged so that households can reduce their food's impact on the climate: reducing the consumption of meat, eating local and eating in-season produce. However, in opposition to this conception of individuals as rational and free to adapt their practices based on the information available to them, we suggest an analytic framework that takes into consideration the fact that food and eating is embedded in everyday and social relationships. Calculating one's greenhouse gas emissions (GGE) provokes an intense moment of reflexivity during which routines are called into question and discrepancies between prescriptions and practices emerge. Drawing our inspiration from, on the one hand, the theory of practice, we examine how the prescriptions are connected to practices, and on the other, using a pragmatic approach, we analyse how individuals call into question their food practices to resolve the contradictions they identify, and devise adjustments. We show how people appraise the context globally, which leads them to subvert the logic of the calculator or address the prescriptions more broadly to lend value to other practices to which they attach importance and consider adapted. This enabled us to highlight vegetable gardening and promoting eating locally produced food as favoured adjustments. The qualitative approach allows us to emphasise how the measuring device, rather than supplying a behaviourist model, makes it possible to render more visible the forms of attachment and categories of judgement mobilised, which do not obey strict accounting logics or a formal, narrow rationality, and to examine "what counts when you're counting".
\end{abstract}

Keywords Carbon Footprint Calculator · Eating local · Vegetable gardening · Greenhouse gas emissions · Adjustement strategies · Daily life 


\section{Introduction}

In France, three quarters of greenhouse gas emissions (GGE) are related to household consumption, mainly housing, transport and food (Lenglart et al. 2010); of this share, food represents on average 16\% (Ipsos Greeninside 2011; cf. also Kim and Neff 2009 for the USA), but if one includes "upstream" emissions during production and distribution, food is then the source of a quarter of the GGE linked to French households' consumption (Ademe 2016). Based on this observation of households' contribution to GGE, a number of associations and public organisations (Kim \& Neff, op. cit.; Rousseaux 2010; Granchamp and Rudolf 2009; Szuba 2009) have developed measuring devices that allow individuals and households to picture more or less precisely the effects of their consumption on the climate. The central idea of these "carbon calculators" is that a better understanding of the impact of food practices on the climate would facilitate the adoption of new habits and practices. This idea of measuring has seduced local authorities who see it as a way for households to appropriate the objectives to reduce GGE defined on both a national level and within the framework of international agreements. They also seduce "concerned" individuals seeking the means to grasp this global issue personally (Granchamp 2015, 2016). Later in this paper, we examine the issue from the perspective of households who use this type of calculator, and analyse how they perceive and react to its prescriptions with regard to food. Among the various aspects of everyday life in which public policy and households seek to reduce their GGE, food is unique in that it is an unavoidable form of consumption, marked by huge variability, and because it is not cancelled out by long-term investments (unlike energy or even transport, at least on a scale for consumers), this lends it greater malleability. However, the perspective of households is never taken into consideration in studies of the different types of calculator (Shirley et al. 2012; Kim and Neff 2009; Druckman and Jackson 2009; Gill and Moeller 2018), whether this involves calculating carbon footprints or more specifically, the food footprint (Kim \& Neff, op. cit.; Baysse-Lainé $2017)^{1}$; we thus considered it necessary to assess their reception and utility in promoting the "ecologisation" or greening of practices (Spaargaren et al., 2012).

We based our study on the results of a qualitative survey conducted as part of an experiment carried out between 2010 and 2011 by a local French authority, the Northern Vosges Regional Natural Park. It asked households living in its area to carry out a series of consumption measurements using a Carbon Footprint Calculation. ${ }^{2}$ A few months after the experiment ended, we met some of the participating households (16 out of 32) and recorded their point of view about the approach and the changes of practices it had led to. We focus on the food section, and observe the extent to which

\footnotetext{
${ }^{1}$ For the USA, see the census of calculators compiled by Kim \& Neff, op. cit.; West et al. 2016; Shirley et al. 2012.; Kenny and Gray 2009 for Ireland, Birnik 2013, Wallén et al. 2004 for Sweden, among others.

${ }^{2}$ The "Personal Carbon Footprint Calculation" was used as the basis for the experiment we studied http://www.bilancarbonepersonnel.org/ consulted on 25 January 2018). It was devised by the French Agency for Environment and Energy Management (ADEME) from 2007; there are now several similar calculators in France offered by consultants and consultancy firms or environmental organisations and all inspired by the ADEME's "Bilan Carbone", which since 2011 has been a patented brand owned by the Association Bilan Carbone (ABC). Since then, other calculators have come to the fore, e.g. the ADEME's "Coach Carbone" and the Fondation pour la Nature et l'Homme. Under the name of "greenApps", the number of these applications that calculate the carbon footprint of various activities has increased significantly (cf. http://www.greenapps.fr/ consulted on 27 February 2017).
} 
they adhere, take into account or, on the contrary, reject the three main prescriptionseating less meat and eating local and in-season produce- suggested to them through the intermediary of the Carbon Footprint Calculator and the organisations promoting it.

In this sense, comparing 21 calculators that take diets into consideration (Kim and Neff $2009^{3}$ ) reveals that eating meat, especially red meat, is the climate-affecting factor most often taken into account and the most differentiating. Organic, local and in-season products are only considered by the more sophisticated calculators. In other words, calculators are not completely "neutral" documenting tools (Granchamp 2016); they implicitly rank practices according to the impact on the climate and operate as indirect prescribers of behaviours since the final result will vary greatly depending on the positive weighting given to certain types of consumption: it will be higher (indicating a stronger impact on the climate) in the event of eating red meat, slightly less for eating white meat and reduced for vegetarianism. ${ }^{4}$ This ranking is reinforced by the line taken by associations and public institutions that promote these calculators. ${ }^{5}$ For this reason, they are known as "prescriptions", in reference to Plessz et al. (2016). Prescriptions are recommendations or advice devised by experts that aim to guide behaviours; they rely on reducing reality with a measuring device by which behaviours are gauged: calories to regulate food behaviours from a dietary and medical point of view (Ascher 2005), and in our case, the quantity of GGE, to guide them from the point of view of their presumed effects on the climate.

However, contrary to the conception implicit in calculators that individuals are rational and free to adapt their practices according to the information and knowledge they possess, we suggest an analytic framework that takes into consideration the way in which food is embedded in everyday social relationships (Halkier and Jensen 2011; Dubuisson-Quellier and Plessz 2013) and infused with multiple constraints and contradictory restrictions. Using a dual theoretical perspective, we propose to analyse these micro-conflicts and the adjustments made by households to adapt their food practices to climate prescriptions.

On the one hand, the theory of practice enables us to focus on the practices themselves rather than individuals and their specific qualities (Reckwitz 2002; Halkier 2009; Dubuisson-Quellier and Plessz 2013). We examine more specifically the connections between prescriptions and practices, an aspect that studies of the theory of practice have not often considered (Plessz et al. 2016). Plessz et al. write, "If sayings

\footnotetext{
${ }^{3}$ The authors identified and compared a total of 83 calculators that consider the environmental impacts of individual or household behaviours, and 21 of these include dietary choices (Kim \& Neff, op. cit.).

${ }^{4}$ Meat is in the top rank of food called into question for its contribution to GGE and reducing its consumption is advised in several prospective scenarios (Agrimonde 2030; Civam Bretagne "Nourrir le monde en 2050" (Feeding the World in 2050). In terms of household consumption, food, according to a 2010 Ipsos/Greeninside survey, represents $22 \%$ of GGE, $15 \%$ of which is from meat and milk compared with $4 \%$ for fruit and vegetables. Furthermore, environmental groups tackling climate change, such as the Climate Action Network (2011), recommend reducing the consumption of meat, especially beef. These recommendations are incorporated in the Bilan Carbone (Carbon Footprint Calculator).

${ }^{5}$ We can cite, in France, the information campaign by the Réseau Action Climat, a member of the Climate Action Network, which launched a campaign in 2008 entitled "Des gaz à effet de serre dans mon assiette" (Greenhouse Gases on my Plate), passed on by the Alsace association Objectif Climat; the Chatham House think-tank that published a report in 2014 linking meat consumption and the impact on the climate ("Livestock - Climate Change's Forgotten Sector: Global Public Opinion on Meat and Dairy Consumption" https://www. chathamhouse.org/publication/livestock-climate-change-forgotten-sector-global-public-opinion-meat-anddairy?dm_i=1TY5\%2C30JL0\%2CBHZILT\%2CAUGSP\%2C1 consulted in December 2017) and also the American organisation The Environmental Working Group, which in 2011 published a guide, "EWG's Meat Eaters' Guide to Climate Change \& Health".
} 
are considered a component of a practice, and if a practice may be considered socially constructed, then the link between practice and prescription may be considered a social fact. This approach leaves room for the existence of a complex and potentially conflicting relationship between spaces of practices and related prescriptions" (Plessz et al. 2016, p. 103, my italics). It is these conflicting relationships between "climate-compatible" food prescriptions and households' actual practices that we analyse below. However, this does not simply involve considering prescriptions as practices to which individuals and households adhere or do not, but also understanding how they assess the context globally, or even subvert the logic of the calculator and its prescriptions to justify other practices they consider important and adapted, in this case, vegetable gardening and home production. We also consider it useful, on the other hand, to mobilise another theoretical perspective - pragmatism. From this perspective, adjustments can be perceived as "experimental procedures" that individuals implement to provide a practical solution to problematic situations (Ogien 2014), and at the same time, the notion of valuation (Dewey 2010) enables people give value to "what one holds dear" (Hache 2011), in this specific case, vegetable gardens and various forms of home production. The aim of this paper is, then, to analyse the ways in which individuals, caught in a network of social relations and norms stabilised in routines, can nonetheless call upon their creativity to adjust their practices, and the role that the calculator can play in this respect. Our hypothesis is that discrepancies exist between the values adhered to by individuals and their practices, but that they strive to implement "situated" adjustments, in other words, adjustments that take into account the various contexts and the conditions of their lives.

In the following section, we present elements of the surveyed population's contextualisation and of the survey itself before developing the main lines of this dual theoretical input enabling us to shed light on the attitudes and positioning of the interviewees when they examine their food practices in light of climate issues, by distinguishing attitudes towards prescriptions (eating less meat, eating locally and inseason) and the adjustment strategies (eating local, organic and home-grown produce), as we explain in our findings. In the "Discussion" section, we return to the relationships between prescriptions and adjustments, and the role that tools such as calculators can play in contributing to the "ecologisation" or greening of food consumption practices.

\section{The experiment in the Northern Vosges Regional Natural Park to raise households' awareness of climate change}

As part of a call for projects from the French Ministry of the Environment regarding climate change, the Northern Vosges Regional Natural Park proposed setting up groups of "Climate Volunteers" from households in the Park's area, who would commit to measuring their emissions using a "Personal Carbon Footprint Calculator" for four areas: home energy consumption, transport, routine expenditure and food. The volunteers were recruited through the written press, radio and local posters. After the first information meeting presenting the main challenges of climate change on various scales (international, national and household), participants were given the chance to join a group of "climate volunteers". They agreed to take quarterly measurements and attend meetings at which alternatives were presented in various fields (e.g. Community-supported agriculture (CSA), for the 
food section). In total, 48 people declared their interest in the project and 32 people signed up as volunteers to take part in the project. It included a sociological assessment, and it was from this perspective that we interviewed 16 households in 2011, i.e. a year after the project began. The aim of the sociological survey was to analyse the obstacles and levers for change in the practices of households' concerned by climate change (Granchamp 2015). This paper focuses on the findings of the food section of the experiment.

The Northern Vosges Regional Natural Park (PNRVN) lies in the north east of France, straddling the Alsace and Lorraine regions and on the border with Germany (Map 1: the location of the Northern Vosges Regional Natural Park). Regional Natural Parks are "rural areas recognised nationally for the value of their heritage and landscape and revolving around a collaborative sustainable development project to protect and promote their heritage. (...) They are managed by an autonomous organisation that brings together all the local authorities that validate the park's charter" (PNRVN 2017). In this case, the PNRVN was approved by the ministerial decree of 30 December 1975, validating the Northern Vosges Regional Natural Park's constitutive charter (PNRVN 2017) ${ }^{6}$ and which now covers 113 municipalities that have adopted its charter.

The rolling countryside rises up to $580 \mathrm{~m}$ above sea level with $60 \%$ forest cover and is marked by traditions that are industrial (foundries, sandstone extraction) rather than agricultural: "This industrial history explains the fact that historically, agriculture in the heart of these uplands was pluriactive subsistence farming by peasants with blue-collar jobs. Agricultural production is concentrated on the richer soils of the foothills and plateau" (PNRV op. cit.). This historical element is not without impact on practices that can still be observed today, as we shall see. Despite being rural, the area is studded with small urban zones, and all the households we met were located near a village or small town. The park's population, estimated at 89,987 (PNRVN, source INSEE 2013), has grown slightly thanks to a positive migratory balance; however, its age structure features an ageing trend, with a large proportion of people aged over 30 and an underrepresentation of younger age groups, especially those aged between 15 and 29 (who leave the area to study and do not return after graduating (Diagnostic territorial, PNRVN, 2011). With regard to the population's socioeconomic characteristics, retired people and bluecollar workers represented $25.2 \%$ and $23.6 \%$ respectively of the total population aged over 15 in 2006. "Although for retired people, figures are lower than the national average of $30.5 \%$, the proportion of blue collar workers is, on the other hand, 10 points higher than the national average of $13.3 \%$. Moreover, the category of "Managerial and intellectual professionals", $4.2 \%$ of the park's population, is underrepresented compared to the national average of $8.4 \%$ " (Diagnostic territorial, p. 15-16).

The sociological profile of the survey participants partially matches these characteristics of the general population living in the PNRVN. Blue-collar and salaried workers are fairly well represented among the households encountered, with 6 of those surveyed from these categories and 9 working in intermediate professions (cf. Graph 1). Therefore, although it has been shown many times that those most aware of environmental causes tend to hold managerial and/or highly qualified positions, they are in fact slightly overrepresented with regard to their presence in the area, but are not the most numerous in our survey population. The benefit of this survey is that it involves relatively diversified social categories.

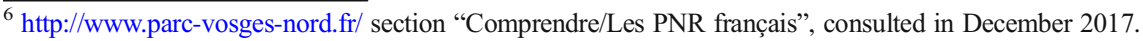




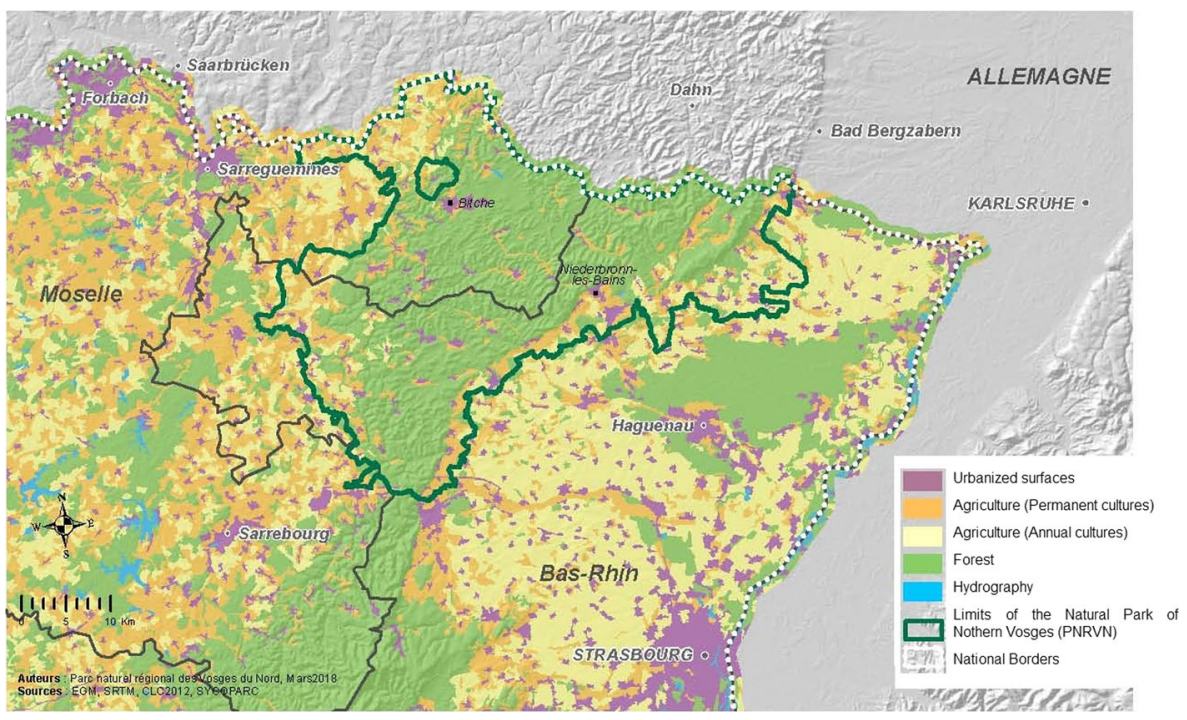

Map 2 Location of the Northern Vosges Regional Natural Park in Europe

The distribution of age groups is relatively uniform: 6 of the 16 couples fall into the 30-45 year-old age bracket with dependent children; at the other end of the scale, 5 couples are of retirement age with independent children and some with grandchildren; lastly, 5 couples were in the 45-60 year-old age group.

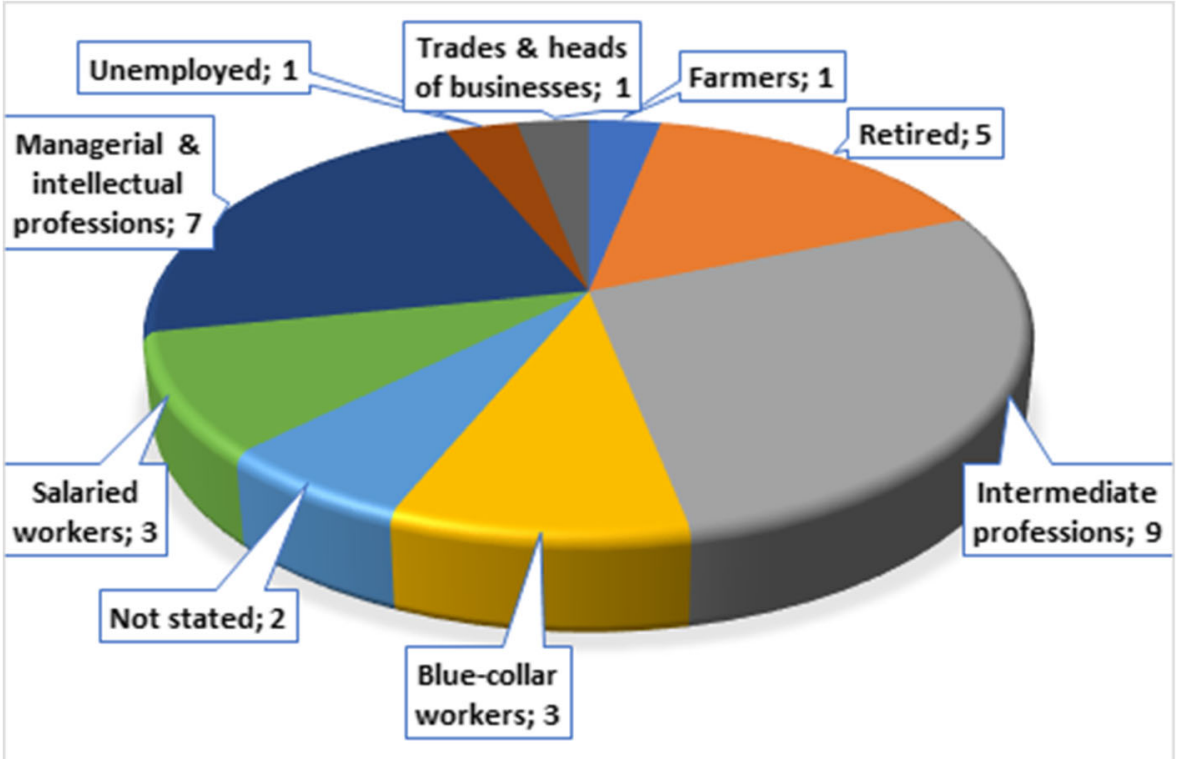

Graph 1 Socio-professional categories of surveyed households (couples). Source: author survey, 2011 ( $n=$ 32 , i.e. the two partners of the 16 households surveyed) 
Participants' stage in life and in particular the arrival or presence of children is, logically, a determining factor in modes of everyday organisation.

These indications about the Park's population and the geographical characteristics of the area provide the contextual elements of the 16 households who were interviewed as part of this survey. We return in the presentation of the method to certain elements of the experiment to measure the carbon footprint of households living in this area, but before this, we introduce the theoretical elements that guided our analysis.

\section{Food from the perspective of climate change: prescriptions, "discrepancies" and adjustment strategies}

Food occupies a central place in our everyday lives and is at the heart of a system of practices whose function is not solely to organise material life but which is also strongly marked by dimensions that are social (Bourdieu 1979) and symbolic (Baudrillard 1970). ${ }^{7}$ As a daily practice, it lies at the crossroads between routines and temporalities as well as associated emotions. For Giddens (1984), the primary function of routines is to facilitate ordinary accomplishments by avoiding the multiplication of small decisions and to contribute to ontological security by protecting from threatening uncertainty. It is only when unforeseen events and crises occur that this "practical consciousness" is suspended, giving rise to a space for reflexivity about our personal practices. In this sense, the Carbon Footprint Calculator created a kind of rupture in ordinary accomplishments that obliged people to call into question their practices from an axiological point of view: the value they place on reducing their impact on the climate can contradict or diverge from the quantity of GGE attributed to their practice (as we see below). However, adapting behaviours to values is not automatic and adjustments can be seen as compromises that may be temporary or lasting.

Here, we consider food practices as embedded in the comforting routines of everyday life, like "black boxes" that mask the contradictions between heterogeneous norms and values. Therefore, shifting attention to practices does not completely avoid the need to analyse the individuals' task of adjusting and adapting. These "adjustments" are not merely the expression of "resistance" to adopting more ecological behavioural norms, as denounced by some politicians (adhering to a behaviourist conception), but instead demonstrate a certain creativity in resolving the problem of ecology and the climate. Discrepancies may be the source of micro-conflicts, or of creativity, or both at the same time through the adjustments made.

We note that three theoretical stances exist with regard to the "discrepancies" between how people understand the prescriptions and their own practices and routines. The first considers that these discrepancies generate an incoherence, a source of private discomfort that the subject strives to reduce by every means possible (Bingen et al. 2010). Giddens (op. cit.) and Kaufmann (1997, 2008) note individuals' need for coherence and the discomfort they experience when they find

\footnotetext{
${ }^{7}$ For Baudrillard, everyday life "is not only the sum of day-to-day events and actions, the dimension of banality and repetition, it is a system of interpretation" (Baudrillard 1970, p. 33).
} 
themselves in contradiction with their beliefs. Kaufmann develops an analysis of these inner micro-conflicts, rooted in everyday life, when routines are in contradiction to values or new representations of the self (for example, when a woman devotes herself to compulsive ironing even though this does not correspond to her idea of the "modern" woman). He refers to social psychology studies and the notion of cognitive dissonance (Festinger 1957) according to which individuals cannot tolerate psychological discomfort when their actions contradict what they know or what they adhere to, and they seek any means possible to reduce this discomfort. However, this notion presents two inconveniences: firstly, it only considers the conscious mentalisation of behaviours, and secondly, even when it signals an individual driver for change, by focusing on questions of identity, this very individualistic approach does not make it possible to understand in greater depth how practices may be adopted more widely. From this point of view, the theory of practice (second stance) offers the chance to go beyond the limitations of identity-based or behaviourist approaches (Dubuisson-Quellier and Plessz 2013). In the context of our research, it leads us to address the prescriptions of adapting food practices to climate change (eating local, less meat and in-season produce) as practices likely to "recruit" supporters. From this perspective, each person appropriates the recommendations or prescriptions in such a way that "standards are what each individual may consider appropriate to his/her case, irrespective of the individual's contentment with the consistency levels that exists between his/her standards and food consumption" (Plessz et al., op. cit., p. 104). Thus, what interests us is observing the way in which individuals devise their "standards" ("standards" are thus always specific to each person or each household). From the point of view of the theory of practice, discrepancies may exist between prescriptions and standards (for example, when an individual decides to apply the prescription partially, as we see in the examples below), but since "saying" and "doing" are two inseparable aspects of practices, the possibilities of analysing "discrepancies" are limited. In fact, individuals struggle with a plurality of logics that they try to reconcile, and prescriptions (all the more so owing to their being multiple) may reinforce their values and what they believe in or attach importance to, or, on the contrary, may be in breach of their actual practices.

The third stance, the pragmatist approach, considers that habits and routines are nothing but practical adaptations: "a habit is kept identical (as a built-in framework for actions) only for as long as the new action that it apprises occurs in a satisfactory way. However, if this is not the case, this same habit changes its status: it becomes the basis upon which a new belief is set to respond to the new practical circumstance. In short, in this dialectical concept, habit is both static and dynamic: it is an 'active rule within us', constantly put to the test of experience (Tiercelin 1993), and not "a provision that forces us to reproduce a conduct that always is the same, nor a cognitive mechanism enshrined in memory that would trigger the reaction to a stimulus" (Ogien 2014). From this theoretical perspective, social agents struggle with a plurality of logics that are, at times, contradictory. The arguments mobilised differ depending on the situation, and the same individual can refer to contradictory logics (Boltanski and Thévenot 1987; Thévenot 2006). The individual coherence towards which everyone tends is, then, more a horizon to be reached than a concrete reality. But it is ultimately this heterogeneity that provides the potential for change, adaptation and evolution. 
The term "prescription" as used here means "advice, recommendations or instructions". 8 By choosing to study what people do, in concrete terms, when they seek to adapt their food practices to reduce their impact on the climate, our approach is a pragmatic one. What we describe as a discrepancy in this perspective is a mismatch between a habit and new practical circumstances, as in the case (which we will return to) in which the individual adheres to but does not or only partially put into practice the prescription. In these circumstances, individuals are led to conducting their own "inquiry" (in the sense of Dewey, op. cit.) to resolve the problem that emerges, and to implementing experimental processes that demonstrate creative improvisation - this is how we should understand the "adjustments" that we go on to develop. In the inquiry situation, agents exercise their critical capacity, reflexivity and, in this case, are as critical of their practices as they are of the means to assess them, in other words, it is not necessarily the calculator that is "right" rather than they themselves. We analyse this work of translating/interpreting the prescription or the comparison between "standards" or stated norms and one's actual practices later in the article.

In the following section, we present the methodological approach we adopted before applying these theoretical principles to analyse how the surveys address food "prescriptions" to help the climate (or in other words, the recommended food practices to reduce the impact of food consumption on the climate), and examine the "adjustments" envisaged to remedy existing discrepancies.

\section{Method}

We conducted semi-directive interviews with 16 households in the Northern Vosges Regional Natural Park a few months after the end of their participation in the experiment using the Carbon Footprint Calculator to measure the impact of their daily activities on greenhouse gas emissions.

Our interview guidelines covered all the sections of the experiment (food, accommodation, travel, consumption). However, among the experiment's four sections, food generally occupied a central position in discussions and was presented by interviewees as the area in which they had learned the most and become most aware of the impact of their consumption on the climate. The interviews were qualitative, using a comprehensive and inductive approach (Paillé and Mucchielli 2003; Kaufmann 1996) seeking to grasp the motivations and meaning the actors give to their practices. The interview guidelines covered the motivations to take part in the experiment and how the interviewees evaluated their experience; we then asked the interviewees what measures they had applied and what they had changed (or not changed) in their practices. With regard to method, we chose to study the question on a household level because households constitute the basic unit of everyday life organisation, and it is on this scale that practical arrangements are constructed and a certain number of compromises have to be made between household members. In order to give an account of this everyday

\footnotetext{
${ }^{8}$ Although Plessz et al. (2016) propose a theoretical framework to which we partially refer to analyse the prescriptions in food practices, they do not give a precise definition of the term, but merely distinguish between messages of an instructional nature from public actors and the norms (standards) that individuals adhere to.
} 
functioning, we conducted most of the interviews with the two partners simultaneously. ${ }^{9}$ The dynamic of the discussions supplied additional information about the micronegotiations and concessions that family life involves, as well as the core values on which couples agree.

For analysis purposes, we proceeded inductively, firstly by identifying everything the interviewees declared that they do - or do not do - to adapt their practices to the recommendations. The recommendations are not directly formulated in the calculator; participants are encouraged to make their own observation by recording their consumption of meat, fish, dairy products, fruit, vegetables and drinks; it is, therefore, partially indirectly, when observing the variable results according to their consumption, that participants are encouraged to opt for solutions that generate lower GGE, and partially through the advice from the association responsible for accompanying the volunteers in the area. For this, we analysed the reports of the meetings organised by the association. With the calculator, the best score in the food section is obtained with a vegetarian diet based on local, in-season fruit and vegetables. Adopting a vegetarian diet is thus indirectly suggested without being explicitly prescribed. However, in its meetings, the association used nutritionists' recommendations estimating that meat requirements could be limited to 2 or 3 times a week. The general prescription is, then, to "eat less meat", which is likely to be interpreted and translated into practices in a very varied way.

We then, for each "prescription" identified, distinguished the extent to which households adhered completely, partially or rejected the practice in question. In this way, we were able to pick out discourse and attitudes at odds with these prescriptions, in other words, the "discrepancies". These discrepancies can lead to discourses justifying or criticising when a recommended practice (prescription) is not adhered to. When the interviewee describes an alternative, a subversion or a form of counterbalance, we call this an "adjustment". When presenting our results, we apply this methodological distinction between practices and adjustments.

\section{Results}

Firstly, we observe that the interviewees interpret the prescriptions, which translates as much with a narrowing as with a broadening of what they perceive as the "standards" or norms of climate-compatible food behaviours. In terms of reduction, for example, both the calculator and the reports of the association meetings include seafood or dairy products in their assessments (calculations or discussions), but these food categories were never mentioned by the interviewees. Conversely, in terms of broadening, the association did not insist upon purchasing "organic" produce for fear of incurring discrimination between households because of the extra cost; however, all the households mentioned it despite its absence in the interview guidelines. Thus, some households perceived organic consumption as a recommendation to which they adhered to varying degrees, whilst for others it was more of an adjustment strategy (see below). On the other hand, various home production practices, first and foremost vegetable gardening, were brought up as means of adjustment to consume local, in-season produce

\footnotetext{
${ }^{9}$ In 6 cases out of 16 , it was not possible to find a timeslot that suited both partners.
} 
and food grown without chemical inputs ("organic" according to the interviewees' common denomination).

\section{Reducing meat consumption}

The interviewees are positioned on a gradient with regard to this recommendation, which distinguishes those who strongly adhere and even tend towards a certain proselytism ( 2 cases) and those who reject it ( 2 cases), whilst the majority of those surveyed adhere in general to the idea whilst highlighting a series of factors that depend on the various constraints acting upon their "good will" concerning this issue. It is undoubtedly one of the prescriptions that give rise to the most unequivocal discourse depending on the weight and role given to meat in one's diet. Firstly, we examine the positions on this gradient, and then the different forms of adjustment envisaged by the interviewees.

\section{Strong adherence: health and climate synergy}

For the first group, eating less meat is perceived as an imperative to which not only they themselves adhere, but one they consider to be a norm that should be adopted by everyone, whether for the benefit of the climate or for health reasons. For example, Cyril, a radiologist in his $40 \mathrm{~s}$ and father of three, is convinced of the benefits of eating less meat.

Cyril: We didn't eat much meat before, and now we eat even less. For several reasons as well, specially for health. That's obvious, health-wise, people eat too much meat, well, in Europe we eat too much. It links the ecology to health, that's for sure. As for vegetables, we already eat a lot of local vegetables, from the garden... so that hasn't changed much. I'm lucky in that my wife cooks a lot.

Through the Carbon Footprint Calculator, a practice he associated with health issues finds itself "ecologised" or greened (Halkier 2009), and the connection between the two issues thus creates a synergy that strengthens adhesion to the prescription ("and now we eat even less [meat]").

Marguerite, a retired senior nurse in her $60 \mathrm{~s}$, married with two adult children, is active in an organisation that promotes canteen menus in which meat is a "taste factor". Like Cyril, she feels that meat consumption is a fundamental environmental and health matter concerning which one should act both individually and collectively. Although they identify meat consumption as a "public problem", they do not mention vegetarianism. "Reducing meat" is a prescription that seems to them easier to adopt since they do not envisage completely cutting it out of their diets, which would mean challenging their food practices far more seriously (purchasing food, devising menus, etc.).

\section{Relative adherence: meat at the heart of domestic balance}

A second group is distinguished by the fact that, whilst adhering to the principle of eating less meat, which the interviewees often aspire to, further reducing meat or cutting it out altogether would upset the domestic balance, whether in terms of taste 
and expectations on the part of certain household members, or in terms of the representations of meat's role in producing strong, healthy bodies.

The case of Sandrine and Alain (40-45 years old, married with 3 children aged 12 and under, she a childminder and he a manager in a large company) provides a fairly good illustration of how this type of recommendation involves negotiation between family members - in this example, the couple.

Sandrine: Well, I've already thought about becoming a vegetarian because... Alain (interrupting): But it's really a question of balance, isn't it, I mean, for our diet, we should eat a bit of everything, a varied diet... I think restricting yourself to a certain category of food means you might not have a balanced diet...

In reality, Sandrine does not seriously plan to become a vegetarian and mentions it rather as a kind of "refuge strategy" to address the question of the health and environmental risks of various foods, but her husband immediately intervenes to postpone the idea.

In a similar way, Simon, in his 50 s and a senior manager in a large company, is happy to eat very little meat with regard to both personal taste and health concerns, but although he feels that eating less meat would be good for his health, he does not, however, think this is so for his son:

Simon: [...] We already, well, we're careful about what we eat, we try not to eat too much meat, well, in fact... I love vegetables but it's not always possible. Because he (pointing to his son), he's a strong lad (laughs), and he works 14 to 16 hours a day in a restaurant, so he needs to eat a little something because otherwise...

For Camille (37, working in sales, married with 3 children; her husband is a blue-collar worker in an automobile company), adherence is more "costly" not only in terms of reorganising the preparation of meals, but also in terms of negotiation with the rest of the family.

Interviewer: Have you reduced your consumption of meat?

Camille: Yes, as much as possible, once a day; it might sound ridiculous to you

but, it's true, before, we ate it at almost every meal. We never eat it in the evenings

now, but at lunchtime, it suits us, five times a week at lunchtime.

As the mother of young, growing children, like many mothers, she questions the suitability of reducing meat consumption. She adheres to the belief of meat's negative effects on the environment and the benefits of reducing its consumption for health reasons, but at the same time, she is convinced that it is necessary to eat meat regularly, especially to ensure children's growth. Furthermore, this consumption is perceived as unavoidable, and very much in demand from members of the family. Her case illustrates how an individual finds him/ herself struggling with contradictory aspirations: satisfying the tastes and demands of family members and reducing consumption for climate or environmental reasons. This leads to a discrepancy between the effective application of 
the prescription, limited by adhering to contradictory values. It is a good example to illustrate the fact that "knowing" is not enough to change behaviour; the belief in the validity of the norm (adherence) may clash with other beliefs or other norms, requiring a whole range of arbitrations in which the individual does not act alone but in a social and relational context.

\section{Rejecting vegetarianism}

Eating less meat is interpreted by some as an incitement to vegetarianism, and although this was not the discourse put forward by the association promoting the use of the Carbon Footprint Calculator, it is an idea to which these people were extremely hostile. Becoming vegetarian involves completely redefining one's identity (Kaufmann 2008), rejected by interviewees either directly (e.g. Franck below) or by claiming this alternative as utopic in light of the many constraints operating on food choices (risk, health, etc.) (e.g. Sandrine).

Franck (66, a retired forest ranger) is totally hostile to the idea. For him, becoming vegetarian is out of the question: "I do not adhere to that", he said. Nevertheless, he applied himself conscientiously in the approach to measure the impact of his diet on the quantity of GGE:

Franck: So, I made myself an Excel table and every day I noted every meal, I asked my wife what she'd put in the food... and well, given that there's not just food in it [the carbon footprint calculator], there's other things... so when they tell us at [name of the association] that pollution is $50 \%$ your fault, by eating meat... well, fine, but there are other things you can do and... or otherwise you become completely vegetarian, and well, I'm sorry but I'm not going to become a vegetarian, I don't agree and, really... I'm not an all-out ecologist, I think we should make an effort, try and weigh the pros and cons and see what we can do... but we should stop messing about and going too far...

In some way, Franck perceives a certain ambiguity in the prescription's communication: although in the beginning it involves "reducing consumption", which can be applied to different degrees, the logic of refining practices during the engagement could progressively lead to vegetarianism. However, in his opinion, vegetarianism corresponds to a certain environmental radicalism, which he does not identify with, and which, for him, even constitutes a deterrent. ${ }^{10} \mathrm{He}$ also displayed strong resistance to this prescription that at the moment is presented as relatively supple, but which he fears will become more rigid. Rather than end up with what he sees as extremism, he prefers adjustment strategies that seem to him more appropriate: procuring local food, home production and reinvesting culinary practices. He does, however, later recognise that these culinary practices have a strong impact on everyday management (we shall return to this point).

$\overline{{ }^{10} \text { Dubuisson-Quellier and Gojard }}$ (2016) obtained similar results with regard to organic food. 


\section{Rejecting the prescription: challenging the calculator}

For Marianne (46, mother of 6 children, works as a home help and her husband is a blue collar worker in a large local company), the problem is not so much reducing meat consumption as eating locally produced meat by procuring it from short supply circuits. She strongly contests the Carbon Footprint Calculator's calculating method that systematically gives a "bad mark" for consuming meat, particularly beef.

Marianne: So in the carbon footprint calculation, for food, when you eat beef or veal or whatever, you get a very black mark, it's bad. But I said, "I don't agree with you!' And I said that I'm fed up with getting a bad mark for that because it's very ecological, doing it this way! Because the farmer takes his veal to the butcher's, and he's got a cold storage unit and as soon as the veal is back, well, I cut it up and I get it for an unbeatable price! And in fact I have enough meat for the whole year! That's how it's done here! And I said, in your calculations, you always use an industrial approach, and it's the same for pork. But I said, "I don't agree!" I go to an AMAP [organisation supporting small, local farms] and buy my pork and each month I go and collect my delivery. The producers sell directly to their customers, so I reckon that's also being an eco-citizen! But because you're looking at it from an industrial point of view, I still get bad marks!

By buying culled cows, ${ }^{11}$ or calves when hay is scarce, she feels she is supporting farming and contributing to a coherent system. Neither does she accept that raising poultry causes lower GGE according to the Carbon Footprint Calculator, and simply does not accept that the quality of the produce and the quantity of GGE can be viewed separately. A "good product", raised locally and outside industrial circuits, is necessarily, for her as for most of those interviewed, an "unpolluted product", "healthy" and therefore low in GGE - even though the calculation is far more complex than that.

\section{Means of adjustment}

Four adjustment practices concerning the reduction of meat can be identified among the interviewees, a single strategy that can encompass different meanings. The first practice, "eating local", by far the adjustment shared by the most interviewees, allows Marianne and Franck to make no changes to their rhythm of meat eating, whilst others, such as Sandrine, consider it a kind of mitigation. The second adjustment practice, which consists of opting for "organic" meat, is very closely linked to the option of eating local produce, as Franck does.

Franck: [...] I buy meat directly from farms I know, from guys who farm organically, properly organic, and they don't sell it more expensively than the others. It's not the farmers selling it more expensively, it's shops. Yeah, I buy beef at, I don't know, 8 euros a kilo! It's the same for mutton!

\footnotetext{
${ }^{11}$ Culled cows are those slaughtered after a period of milk production, when they are too old.
} 
In addition to the more ecological production mode, what influences his choice of procurement is first and foremost proximity to the farmer, which gives him greater confidence (these farmers are "properly" organic) and means he can pay a better price by avoiding intermediaries. Marianne expressed the same thing ("I cut it up and I get it for an unbeatable price!").

The third type of adjustment consists in transferring meat consumption to poultry or pork ("white meat") or fish. This is the strategy suggested by the calculator because the GGE associated with their production are lower. The interviewees were relatively unfamiliar with the incremental impact of poultry and pork production in terms of GGE, and although in the beginning they linked this more closely to health issues, the Carbon Footprint Calculator did, in a way, help "green" this type of consumption. This is a type of adjustment that would reduce the impact of meat consumption without becoming a vegetarian (since, as we have seen, vegetarianism had an off-putting effect); however, it was not the strategy most often cited by interviewees (twice). In reality, "white" meat tends to be combined with local supply circuits.

The fourth type of adjustment we encountered consists in promoting home production and vegetable gardens. This is what Cyril explains when he mentions their consumption of vegetables from their garden. The same is true for Franck, who feels he has reduced his meat consumption by replacing it with fish and above all, eating many vegetables from his vegetable garden. Home-grown vegetables are thus used as a partial substitute for those who eat little meat (as well as those with strong financial constraints) as a form of mitigation.

\section{Eating local and in-season produce}

The second prescription in the Carbon Footprint Calculator and conveyed by numerous messages linking the climate to food involves eating local, in-season produce. Thirteen of the 16 households mentioned short supply circuits (AMAPs, buying direct, vegetable box deliveries or producers' shops). Although adherence to this principle is widespread, it can take forms that are more or less "activist" and systematic. The notion of "local" in particular can be more or less extensive (and elastic).

\section{Banning exotic and out-of-season fruit}

Exotic fruit is not heavily stigmatised by the calculator (less so than meat or cheese). At most, the association organising this project drew attention to the means of transportfavouring a product transported by sea rather than air, and not grown in greenhouses (when this information is available), and, potentially, choosing a fair-trade label. Excluding out-of-season fruit is a norm adopted by everyone (no strawberries during the winter); however, eating exotic fruit (oranges, bananas, pineapple) was found to be somewhat contrary to the objective of reducing the impact on climate change, whilst being relativised, as was the case for Cyril.

Cyril: well, obviously, this isn't a good example because we're eating pineapple today. But if you don't eat huge amounts of exotic fruit and if you don't eat out-ofseason fruit, which we never usually do, in my opinion, in their opinion too, it's not that bad [in the Carbon Footprint Calculator]. 
In a certain way, the Carbon Footprint Calculator is used here to justify a measured behaviour: if consumption modes are reasonable, one is not obliged to take radical measures.

\section{Local but not self-sufficient}

Although they adhere to the idea of "eating local", the interviewees consume produce such as pineapples, bananas and oranges. Two variants emerged in their reactions: either, like Cyril, they minimised the impact (he claimed that it was "a bad example" and "it's not that bad"), or they "owned" it and do not envisage giving up these fruits that have become part of everyday consumption. For Camille, when it is not possible to obtain everything locally, one has to resort to imported products:

Camille: In W [name of a small town], there's a farmer who sells his produce directly. I buy almost everything from him. Or I grow it myself in my vegetable garden, but it's not enough for me. Because I don't think I can grow bananas in my vegetable garden!

Sandrine is beginning to take this new information into consideration when buying food, which influences her choices without, however, renouncing products she appreciates.

Sandrine: (...) Yes, it's true that before, when I bought a pineapple, for the carbon footprint I never thought about the air freight, but it doesn't necessarily mean... it hasn't changed my habits. It's true I do try to eat local, in-season products, but I do buy pineapples sometimes.

In other words, the norm of eating local, in-season produce can be subject to various "accommodations", as long as it does not happen too often (as is the case for Cyril), with paying attention to other purchases being used to compensate what can be perceived, along the same lines as a weight-loss diet, as "straying".

There is also the case of Alice (46, 2 children, quality manager):

Alice: We eat oranges and bananas in the winter, and we'll try and find them as locally as possible but we're not going to deprive ourselves of oranges and bananas in the winter. But in the medium term, we planted some fruit trees a couple of weeks ago, so maybe in two years I'll have apples and pears from my orchard!

Faced with this discrepancy between the objective and the actual practice, Alice mentions an adjustment strategy: paying attention to the source ("we'll try and find them as locally as possible").

\section{In-season as another meaning of local}

In the Natural Park area, as they did in the entire region, the villagers used to plant orchards that were tended collectively. These old orchards are still maintained by 
associations (of which two of our interviewees are members), and have left their mark in people's memories. They represent sources of personal experience with the seasons and place, as Charles (48, married to Alice, father of 2 and a town employee) recalls in an episode from his childhood.

Charles: We were familiar with in-season fruit as when we were kids, we used to play in the forest when there were chestnuts and stuff like that and as soon as it was the season and we were peckish, we'd just go there, we'd just go to the orchard and help ourselves, there were loads [...] all sorts of cherries, all sorts of apples, it was all natural, 'who's hungry?' and off we'd go from the woods and we'd go round the orchard and fill up the baskets on our bikes and go back into the woods.

\section{Adjustment strategies: the different versions of local}

In addition to this discrepancy that they seem to take responsibility for, the interviewees implement adjustments that aim to reduce it: Camille endeavours to buy organic produce to reduce transport and packaging, and grows her own vegetables in the same spirit; Alice has planted fruit trees and hopes to reduce her consumption of imported fruit when her orchard becomes productive. Once again, we see investment in organic food and home production (a more advanced form of local produce) as two means of adjustment. Procuring food locally almost becomes a lifestyle element for some of the interviewees such as Marianne, who buys her oil made from local walnuts, has her fruit pressed for juice in a local press (along with three other interviewees) and collects overripe fruit from neighbours to make liqueurs, etc.

\section{The supermarket seen as the antithesis of local, in-season food}

The interviewees mentioned another adjustment strategy, one we did not expect, namely reducing their use of the supermarket. Supermarkets are associated in their discourse with waste, produce that has travelled great distances and with a significant impact in terms of GGE, unlike local produce, ${ }^{12}$ as well as superfluous packaging. For the interviewees, reducing their use of supermarkets represents a marked symbol of change in consumption models, for, as Suzanne rightly observes, becoming a member of an AMAP, going to the local or buying directly from local producers entails a whole series of reorganisations and adjustments of ones habits:

\footnotetext{
${ }^{12}$ However, we should point out that when we consulted the scientific literature available, especially concerning the notion of "food miles" or in other words, the fact that the more miles a product travels during its production and distribution, the greater the impact on the climate and environment (The "RAC - Réseau action climat, (2010) brochure cites a pot of yoghurt), there is no consensus about the virtue of local productions. Transport is not the only aspect to consider; production conditions - extensive or intensive for raising animals, in heated greenhouses or in fields for vegetables - have just as great an effect on the calculation of the GGE of the product under consideration (cf. Pirog et al. (2001); Mundler and Rumpus (2012); Weber and Matthews (2008); Blanke and Burdick (2005). The environmental working group (2011).
} 
Suzanne: I mean, I almost never go to the supermarket, that's a lifestyle habit too... There's the farmers' market in the high season, from April to November, just down the road. We're members of an AMAP too, for dairy produce, and we're setting one up ourselves for parcels of meat.

It is not simply procuring food from nearby that allows the interviewees to avoid supermarkets and industrially produced food, perceived as being disconnected from the seasons and productions sites; here, as for reducing meat consumption, home production is envisaged as an adjustment possibility.

\section{Eating "organic"}

As we have already specified, this prescription does not appear in the experiment (or in the Carbon Footprint Calculator or in the association's accompaniment) and yet it emerges as such in interviewees' discourse. Three types of reaction were identified: those who reject it (too expensive, fear that it generates high GGE because of transport), those who adhere to it on condition that it is local and/or who eat it intermittently (Lamine 2008), and those with a far more militant consumption, who make it a key element of their lifestyle, associating it with "purity". For Anaïs in particular (34, young mother, a school psychologist), the choice of organics is associated with a series of wider practices, a general life philosophy that includes breastfeeding and the consumption of products judged to be more "healthy", for example, and swapping supermarkets for organic shops. In this case, the organic option is more closely connected to a kind of quest for purity and naturalness in food consumption (Adamiec 2014) than consideration of the impact on the climate.

"As far as possible, we try and put organic food on our plates", declared Michel (34, married, no children, sales representative). With regard to eating "organic", we saw above how this choice could be adopted to minimise the presumed impact of eating meat or exotic fruit. This may appear relatively paradoxical if one considers as commonplace the discourse of certain interviewees who associate "organic produce" with "food miles"; Michel mentions the contradiction of importing organic produce from far away.

Michel: so as far as possible we go for organic and local, anyway, we always go for those two things, but then again, importing organic food from the other side of the world, that's pointless, so we try and find a balance.

The other commonly held belief about organics is the price, more specifically in supermarkets and organic food shops that are strongly criticised (see Franck above). In reality, the interviewees were only unanimous about "organic" when it is local-and the local qualities outweigh "organic" quality. Local is thus doubly invested with ecological and social qualities: it makes it possible to support local farming (Marianne), reduce food miles and, at the same time, prices. Along the gradient of adherence to organically farmed produce, we thus find diverging attitudes, but more specifically with regard to the organic food bought from shops. 


\section{Vegetable gardens and home production: an overall method of adjustment?}

Among the ways of reducing food's impact on the climate, vegetable gardening emerged in a way that was totally unexpected. Home production is not part of the advice given by the association working with the inhabitants of the Northern Vosges Regional Natural Park and does not appear in any of the communications from climate mediators. However, it is a practice that is widespread amongst the people interviewed with only two households not possessing a vegetable garden. ${ }^{13}$

Vegetable gardening is a practice invested with strong symbolic meaning by the interviewees. Even more than "eating local", tending their gardens represents a means of concrete action with regard to a problem as general as climate change. On the one hand, food production and distribution systems have reached such a degree of industrialisation and complexity that they give the impression of escaping the grip of individuals and the choices they can make. And on the other hand, climate change is problem of global risk on a scale of experience totally different from that of everyday life. Vegetable gardens allow them to make a connection between general knowledge and practical experience, between knowing and doing. It is also a primary medium to pass down a "love of nature" over generations, used as a medium and reinterpreted in light of the climate problem. Through vegetable gardening in a family setting, several interviewees felt their environmental awareness had been raised and through this, they explain the way in which they came to feel involved with the climate.

Franck: (...) And well, I had a garden, my grandparents used to have a garden... and by having a garden, you already feel a bit more involved because... you can make your own compost and tend your garden as well as possible without using too many chemicals... so that's what in some way led me to this...

This role of transmission is found in several accounts that also reflect the working-class past that characterises this region, and the associated home production practices.

Cyril: In fact, my parents always had an allotment, you know, the gardens you rent, and well, they always had this type of garden. In S. [town in Lorraine] we had to pay a rental to the railway company and there was a garden... When I say garden, I mean a vegetable garden. So I always used to see my mother making preserves, preserving vegetables and making jam and things like that.

With this knowledge passed down by their parents, these young parents, like Cyril or Sandrine and Alain, invest the vegetable garden with an educational role for their children, especially as a teaching tool for taste, even the taste for effort, to encourage them to be aware of the value of produce.

\footnotetext{
${ }^{13}$ One of the households was composed of a company director and a senior manager, and the other a livestock farmer and an executive secretary; however, the latter was setting up an AMAP after participating in the PRNVNs' experiment.
} 
Alain: (...) it's always kind of with the intention of trying to involve the children in this aspect too, so that they can discover vegetables and that we don't just buy tomatoes from the local supermarket, they grow in the garden too.

These home production practices are an attempt to break away from mass distribution and the agri-food industry market, and aim to procure produce perceived as "healthier" as well as obtaining certain autonomy, even an impression of no longer being dispossessed by the disconnection of industrial farming systems. This is why we talk of home production rather than home consumption because it is a key act that involves the desire to eschew the role of passive consumer. This home production from vegetable gardens leads to an entire series of associated practices to transform/preserve the produce. Home production can be refined even further; it is a question of availability, domestic organisation, know-how, taste, etc. Among those surveyed, some of the women made fruit bars, sweets and dried fruit to avoid artificial colorants, and at the same time, potential allergies (this is the case for Cyril's wife), and to educate their children in a different relationship with taste, thought to be healthier and more natural, or to avoid packaging (Marianne). These practices are the medium to teach one's children about taste, the value of produce and passing on knowledge in a shift away from the market-driven, industrial world.

Admittedly, as Jean points out, home production is not without certain constraints that, despite his egalitarian discourse, are more likely to be assumed by women.

Jean (retired manager in the building trade): So when you get home in the evening, you don't cook anymore, you just find something quick. But in the old days, the women who were at home had time to cook. They could make food, see. And it didn't cost much. Because making meals where you have to cook the meat for four hours, you can't do that when you work. At the time, it was the women, it could have been men, I don't care if it's the man who stays at home and the woman goes out to work, it's all the same. But someone has to be there to cook. Cooking from scratch means you live much, much more cheaply. You need to make things with vegetables, and potatoes, cook stuff, fritters, cook good things! Not junk food, not things that... And it's cheap! And it means people can live better. But it would disrupt the whole system, wouldn't it?

Home production practices require time and availability (e.g. Marianne who cuts up meat herself); Jean emphasises the contradictions between consumer accountability and the constraints imposed by a society that no longer allows people to take the time to grow food, learn to prepare food and cook. Nevertheless, contrary to the trend recorded in studies of consumption involving purchasing ready-made products (Herpin and Verger 2008), these interviewees are redeveloping skills (making preserves), arousing their creativity (recipes for jams and desserts) and feeling a certain pride in what they make themselves. The vegetable garden as the main home production practice linked to an entire system of practices emerges as the symbol of a lifestyle considered more ecological and coherent; the discrepancy or contradiction is then transferred to global social logics or the "system" (as Jean calls it). 


\section{Discussion}

Participating in the Carbon Footprint Calculation and the dialogue with the interviewer are two specific moments when the ordinary accomplishment of practices is suspended, and when individuals are encouraged to reflect (Giddens 1984), challenging practices that were previously undertaken routinely. In this way, the exercise in reflexivity reveals "discrepancies" between the prescriptions to adapt food to the climate and households' actual practices. The normative thrust of these prescriptions leads to microconflicts involving rivalling representations, norms and routines, perceptible in the justification discourse and even more so in what people designate as alternative practices, compensation and efforts to "adjust" their food practices. We thus observe how people make adaptation choices "adjusted" to their conditions and their material, organisational and relational constraints.

The prescription to reduce meat consumption is especially revealing; this is a particular target for climate NGOs' awareness-raising campaigns, ${ }^{14}$ but although most of the interviewees adhered to the idea of eating "little" meat (with great variation from one person to another), they anticipate any form of radicalisation by rejecting vegetarianism. The Carbon Footprint Calculator tends to "green" this prescription that originally was associated more closely with health issues: when they committed to the calculation process, the interviewees did not know about the link between eating meat and the impact on the climate. However, despite discovering the link between health and climate issues, we were able to observe how relating prescriptions and practices remains complex. Faced with the discrepancies revealed by the calculator between their consumption and their values, they envisage changes in their practices, but these are neither direct nor systematic. They take into account other parameters such as the financial situation - those with the strongest financial constraints thus have the possibility to promote the way in which they "make a virtue of necessity" - as well as health, age and representations of nutritional requirements or representations of what constitutes a product that is "healthy" and "good for the environment".

Ultimately, we note that the prescriptions are not taken literally and the way in which interviewees analyse the discrepancies between their practices and the prescriptions involves a series of translations, interpretations and reassessments of what is desirable or appropriate, from their point of view, to succeed in "greening" daily life in line with climate issues. This is noticeable in the way in which the interviewees envisaged the role of vegetable gardens as a key element in a system of ecologically virtuous practices; in the same way, "organic" food (although this is not unanimous) has, in the eyes of some interviewees, a status equivalent to an adjustment practice that lends coherence. These two examples reveal the extent to which the measuring operation is an analysis medium that goes beyond accounting in the strictest sense, mobilising judgment categories that tend to be made invisible by using the measurement. It is thus interesting to ask "what counts when we're counting", or to paraphrase Dewey's observation (1938, quoted by Cottereau 2016) that "the quantitative alone can never bear the entire weight of measurements". ${ }^{15}$ In other words, measurements only make

\footnotetext{
${ }^{14}$ Cf. Note 8 .

${ }^{15}$ Studies measuring GGE from food or other aspects of daily life could be inspired and in return, inspire economic sociology studies on measurements, such as those by Cottereau (2016).
} 
sense in conjunction with the valuation of certain practices by the same yardstick that prescriptions are evaluated. This idea contains two developments. Firstly, the type of values mobilised in the counting operation undoubtedly affects the capacity to appropriate and translate; the prevalence of "local" as a mode of adjustment between practices and prescription could thus be explained by the fact that the Carbon Footprint Calculator's method of calculating, based on accounting in terms of GGE, is far less revealing and more complex to integrate than accounting in terms of food miles. However, just because it is "local" does not necessarily mean a product is better for the climate. Moreover, this shows in a more general way the task of assessing and finding equivalences that aim to make practices comparable from an ecological and climate point of view. ${ }^{16}$ Secondly, weighed against each other are, on the one hand, GGE, which tend to reduce practices into accountable, substitutable and "standalone" units, and on the other hand, forms of valuation (Dewey 2010) or the way in which people manage to give value to their attachments, the networks of actors on which they base the feeling of proximity and the links between past and present through memories. Marianne's comments when she denounces the Carbon Footprint Calculator as being in thrall to the "industrial approach" whilst her personal relationship of proximity is rooted in the area illustrate this tension. Similarly, Charles, who, recalling his childhood, links the present and the past and demonstrates his attachment to place. Through memories, attachments, family histories, the transmission of knowledge and a certain type of relation to place (or even the world) for which vegetable gardens are the medium, the interviewees made the connections between their personal experience, rooted in their daily lives and the problem of climate change. This issue, perceived in the beginning as too global, too vast, can only be comprehended by tangible practices, revealing "what one holds dear". In this semi-rural area with a strong working-class legacy, vegetable gardens are a preferred medium for this. Through them, these households attempt to reappropriate agency with regard to their food as a fundamental dimension of the chance to "green" their lifestyles. However, as we have shown, this does not occur without tensions and contradictions.

\section{Conclusion}

The aim of this article was to analyse jointly the ways in which households received a tool to measure greenhouse gas emissions (GGE), the Carbon Footprint Calculator, and the corresponding prescriptions with regard to food. By analysing the "discrepancies" between "climate-compatible" food prescriptions and actual practices, we attempted to give an account of the extent to which food practices are embedded in far broader sets of practices and social relations. Combining an approach inspired by the theory of practice and pragmatism has proved to be effective to highlight "situated" adjustments, in other words, the way in which people envisage reducing the discrepancies between the prescriptions and their practices that takes into consideration contexts and standards of living. This also applies to the way in which they assess the context globally, leading them to subvert the calculator's logic or address the prescriptions in a broader way to

\footnotetext{
${ }^{16}$ Especially when interviewees mention types of arrangements and compromise with regard to the prescription to eat local, in-season produce.
} 
promote the value of other practices to which they attach importance and that they perceive as adapted (e.g. vegetable gardening and promoting "local").

The measuring tool thus creates a reflexivity situation that plunges individuals into the task of questioning, evaluating and valuating their practices, making more visible the forms of attachment and the judgment categories mobilised, which do not obey strict accounting logics or a narrow, formal rationality. In particular, we revealed that, far from being strictly "neutral" and unequivocal, this type of tool generates the task of interpreting both prescriptions and everyday practices, in a sense that contributes not only to greening practices but also to expressing personal satisfaction, a kind of pride and feeling of accomplishment linked to individuals' taking back charge of areas of life in a shift away from the industrial and market-driven world.

Furthermore, it is reductive to return without question to the behaviourist conception of individual action contained in the model for change of a tool such as this: quantitative objectivation is not, per se, enough. To be more precise, as we mentioned in the discussion, the measurement cannot be dissociated from the evaluation. The unit of measurement becomes secondary to the creation of a narrative that makes it possible to bring together disparate elements of the experiment and to make certain practices comparable with regard to certain aspects. Consequently, our perspective does not lead us to minimise the benefit of carbon calculators but instead to study realistically the (sometimes unexpected) ways in which these tools are used in concrete practical dynamics.

In the process, this subjective comprehension of the link between food and climate can always produce contradictions, errors of appreciation and the necessary readjustments. The chosen theoretical framework enabled us to highlight that the link between prescriptions and practices is neither direct nor fully capable of being anticipated by those who designed it: on the one hand, the reflexivity used by the interviewees leads them to associate these prescriptions with "unexpected" practices (from the point of view of those who devise them), and on the other hand, perfecting practices also depends upon enhancing knowledge in a reflexive dynamic. These practices are not, then, "written in stone" and can evolve depending on the appreciation of the context.

\section{References}

Adamiec, C. (2014). Devenir sain : morales alimentaires, pratiques de santé et écologie de soi, thèse de doctorat en sociologie, sous la direction de N. Diasio: Université de Strasbourg.

Ademe (2016), Manger mieux, gaspiller moins. Pour une consommation alimentaire plus durable, Guide pratique, June 2016, 24 p. http://www.ademe.fr/manger-mieux-gaspiller-moins

Ascher, F. (2005). Le mangeur hypermoderne Une figure de l'individu éclectique. Paris Odile Jacob 331 p.

Baudrillard J. (1970), La société de consommation, Paris, Gallimard-idées, (rééd. de 1978), 318 p.

Baysse-Lainé A., (2017), L'empreinte spatiale des approvisionnements alimentaires locaux : un modèle graphique, M@ppemonde, n. 122 ·Article mis en ligne : 09/2017 http://mappemonde.mgm.fr/122as4/

Bingen J., Sage J., Sirieix L., (2010). Consumer coping strategies of eating local, in Emilie Coudel, Hubert Devautour, Christophe-Toussaint Soulard, Bernard Hubert, ISDA 2010, Jun 2010, Montpellier, CiradInra-SupAgro, 9 p. <hal-00525606>.

Birnik, A. (2013). An evidence-based assessment of online carbon calculators. International Journal of Greenhouse Gas Control, 17(September), 280-293.

Blanke, M. M., \& Burdick, B. (2005). Food (miles) for thought. Energy balance for locally-grown versus imported apple fruit. Environmental Science and Pollution Research, 12(3), 125-127. https://oi. org/10.1065/espr2005.05.252.

Boltanski, L., \& Thévenot, L. (1987). De la justification. Paris, Gallimard: Economies de la grandeur. 
Bourdieu P., (1979), De la distinction, critique sociale du jugement, Paris, Ed. de Minuit, 672 p.

Cottereau, A. (2016). "Ne pas confondre la mesure et l'évaluation : aspects de l'ethnocomptabilité", Revue des politiques sociales et familiales, n. 123, Joindre les deux bouts. Equêtes d'ethnocomptabilité, 11-26. https://doi.org/10.3406/caf.2017.3179 consulted in June 2018.

Dewey, J. (2010 [1927]). Le public et ses problèmes, translated by Joëlle ZASK. Paris: Gallimard.

Druckman, A., \& Jackson, T. (2009). The carbon footprint of UK households 1990-2004: a socioeconomically disaggregated, quasi-multi-regional input-output model. Ecological Econonmics, 68(7), 2066-2077.

Dubuisson-Quellier, \& Gojard, S. (2016). Why are food practices not (more) environmentally friendly in France? The role of collective standards and symbolic boundaries in food practices. Environmental Policy and Governance, 26, 89-100. https://doi.org/10.1002/eet.1703.

Dubuisson-Quellier, S., \& Plessz, M. (2013). La théorie des pratiques. Sociologie, 4(4) [mis en ligne le 28 janvier 2014, consulted on $25^{\text {th }}$ January 2018] URL : http://journals.openedition.org/sociologie/2030.

Festinger, L. (1957). A theory of cognitive dissonance. Stanford, CA: University of California Press.

Giddens, A. (1984). The constitution of society: outline of the theory of structuration. Cambridge, University press.

Gill, B., \& Moeller, S. (2018). GHG emissions and the rural-urban divide. A carbon footprint analysis based on the German Official Income and Expenditure Survey. Ecological Economics, 145, 160-169.

Granchamp, L. (2015). Défi climatique et écologisation à petits pas. Changement des pratiques quotidiennes ou résistances? Ann. Sci. Rés. Bios. Trans. Vosges du Nord-Pfälzerwald, 18(2015-2016), 90-112.

Granchamp, L. (2016). Le sens de la mesure : Quantifier et modérer les émissions de gaz à effet de serre par la consommation des ménages. Revue des Sciences sociales, 55, 82-91.

Granchamp L. \& Rudolf F., 2009, « Calculer pour sauver le climat ? Responsabilité, autocontrainte et rationalisation des modes de vie face au changement climatique », in Michelle Dobré \& Salvador Juan (dir.), Consommer autrement. La réforme écologique des modes de vie, L'harmattan, p. 187-198.

Hache, E. (2011). Ce à quoi nous tenons. In Propositions pour une écologie pragmatique. Paris: La découverte.

Halkier B., "A practice theoretical perspective on everyday dealings with environmental challenges of food consumption", anthropology of food [En ligne], S5 | September 2009, published online on $10^{\text {th }}$ September 2009.

Halkier B., Jensen I., (2011), "Doing "healthier" food in everyday life? A qualitative study of how Pakistani Danes handle nutritional communication", Critical Public Health, vol. 21, no. 4, p. 471-483. DOI : https://oi.org/10.1080/09581596.2011.594873.

Herpin, N., \& Verger, D. (2008). Consommation et modes de vie en France : une approche économique et sociologique sur un demi-siècle. Paris: La Découverte.

PNRVN-Parc Naturel Régional des Vosges du Nord. (2011). Diagnostic territorial, http://www.parc-vosgesnord.fr/ consulted in. January, 2018.

IPSOS, Logica Business Consulting, Green Inside, (2011). « Observatoire du bilan carbone des ménages », March 2011. www.ipsos.fr/sites/default/files/attachments/observatoire-bilan-carbone-menages.pdf (last consulted in February 2017).

Kaufmann, J.-C. (1996). L'entretien compréhensif, Paris, Nathan, collection Université (128 p).

Kaufmann, J.-C. (1997). Le cour à l'ouvrage. Paris, Nathan: Théorie de l'action ménagère.

Kaufmann, J.-C. (2008). Quand Je est un autre. Armand Colin: Pourquoi et comment ça change en nous.

Kenny T. \& Gray N.F., (2009) Comparative performance of six carbon footprint models for use in Ireland, Environmental Impact Assessment Review, Volume 29, Issue 1, January, 1-6.

Kim, B., \& Neff, R. (2009). Measurement and communication of greenhouse gas emission from U.S. food consumption via carbon calculators. Ecological Economics, 69, 186-196.

Lamine, C. (2008). Les intermittents du bio. Pour une sociologie pragmatique des choix alimentaires émergents (344 p). MSH: Quae éditions.

Lenglart, F., Lesieur, C., \& Pasquier, J.-L. (2010). Les émissions de CO2 du circuit économique en France. L'économie française, Insee Références, July, 2010, 101-125.

Mundler, P., \& Rumpus, L. (2012). The energy efficiency of local food systems: a comparison between different modes of distribution. Food Policy, 37, 609-615.

Ogien A., " Pragmatismes et sociologies », Revue française de sociologie 2014/3 (Vol. 55), p. 563-579.

Paillé P. \& Mucchielli A. (2003), L'analyse qualitative en sciences humaines et sociales, Paris, A. Colin, coll. U., 424 p.

Pirog, Rich S.; Van Pelt, T., Enshayan, K. \& Cook, E., (2001). "Food, fuel, and freeways: an Iowa perspective on how far food travels, fuel usage, and greenhouse gas emissions", Leopold Center Pubs and Papers, no. 3, http://lib.dr.iastate.edu/leopold pubspapers/3 
Plessz, M., Dubuisson-Quellier, S., Gojard, S., \& Barrey, S. (2016). How consumption prescriptions affect food practices: assessing the roles of household resources and life-course events. Journal of Consumer Culture, 16(1), 101-123.

RAC - Réseau action climat, (2010) Des gaz à effet de serre dans mon assiette, http://www.rac-f.org/Des-gaza-effet-de-serre-dans-mon consulted on 28th January 2016.

Reckwitz, A. (2002). Toward a theory of social practices: a development in culturalist theorizing. European Journal of Social Theory, 5(2), 243-263.

Rousseaux I. (2010), Etat des lieux international des programmes de carte carbone individuelle $<$ hal005521330>, consulted 28th April 2016.

Shirley, R., Jones, C., \& Kammen, D. (2012). A household carbon footprint calculator for islands: case study of the United States Virgin Islands. Ecological Economics, 80, 8-14.

Spaargaren, O., \& Loeber. (2012). Food practices in transition. Changing food consumption, retail and production in the age of reflexive modernity. Routledge. https://doi.org/10.4324/9780203135921

Szuba, M. (2009). Le rationnement pour changer les modes de vie ? In M. Dobré \& S. Juan (Eds.), Consommer autrement. La réforme écologique des modes de vie (Vol. 2009, pp. 267-275). L'Harmattan.

The Environmental Working Group, (2011), "EWG's meat eaters guide to climate change \& health", https://www.ewg.org/meateatersguide/ consulted in February 2018.

Thévenot, L. (2006). L'action au pluriel : régimes d'engagement. Paris: La découverte.

Tiercelin, C. (1993). C. S. Peirce et le pragmatisme. Paris: Presses universitaires de France (Philosophies).

Wallén, A., Brandt, N., \& Wennersten, R. (2004). Does the Swedish consumer's choice of food influence greenhouse gas emissions? Environmental Science \& Policy, 7, 525-535.

Weber, C. L., \& Matthews, H. S. (2008). Food-miles and the relative climate impacts of food choices in the United States. Environmental Science \& Technology, 42(10), 3508-3513. https://doi.org/10.1021 /es702969f.

West, S. E., Owen, A., Axelsson, K., \& West, C. D. (2016). Evaluating the use of a carbon footprint calculator: communicating impacts of consumption at household level and exploring mitigation options. Journal of Industrial Ecology, 20(3), 396-409.

Publisher's note Springer Nature remains neutral with regard to jurisdictional claims in published maps and institutional affiliations.

\section{Affiliations}

\section{Laurence Granchamp ${ }^{1}$}

Laurence Granchamp

laugran@unistra.fr

1 DynamE UMR 7367 Université de Strasbourg/CNRS, Misha, 5 allée du général Rouvillois, 67083 Strasbourg cedex, France 